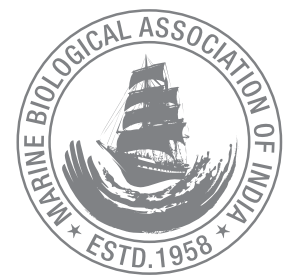

\title{
Fishery, biology and stock status of Priacanthus hamrur (Forsskal, 1775) exploited off Kerala coast
}

\author{
P. K. Seetha, P. U. Zacharia*, K. S. Sobhana and S. Sivakami \\ ICAR-Central Marine Fisheries Research Institute, P.B. 1603, Kochi-682 018, Kerala, India. \\ *Correspondence e-mail: zachariapu@yahoo.com
}

\begin{abstract}
The present paper attempts to describe the fishery of priacanthids along Kerala coast during 2007-15, along with insights into certain aspects of the biology and stock status of the dominant species Priacanthus hamrur which formed more than $80 \%$ of the priacanthids landed during this period. The length-weight relationship estimated show that there is no significant difference in $b$ values of male and female and the equation derived for sexes pooled $W=0.000047038 L^{2.76}$. Sex ratio revealed dominance of females over males (1:1.5). Spawning season of $P$. hamrur was from June to October with a peak in August. Growth parameters estimated were, $L_{\infty}=404.25 \mathrm{~mm}, K=0.58$ year $^{-1} t_{0}=-0.1370$. Total mortality estimated was $Z=3.70$, natural mortality $M=1.13$ and fishing mortality $\mathrm{F}=2.57$. The exploitation rate $(\mathrm{E})$ of $P$. hamrur in Kerala coast was estimated at 0.69 which is above the optimum level.
\end{abstract}

Keywords: P. hamrur, fishery, biology, stock structure, Kerala coast

\section{Introduction}

Priacanthids or Bull's eye (Family: Priacanthidae) have emerged as important demersal resource along the Kerala coast with the landings registering an almost two-fold increase from 2,247 tonnes (t) in 2007 to $4,128 \mathrm{t}$ in 2015 . The fish is mainly caught by multiday trawlers which operate in the depth range of 30-150 m. Among Priacanthids, Priacanthus hamrur is the common species exploited along the Kerala coast. Various studies based on exploratory surveys (Vijayakumaran and Naik, 1988; Sivakami, 1990; Sivakami et al., 1998; Philip and Mathew, 1996a, b ; Varghese, 1995, 1998; Premalatha, 1997) are available on the distribution and abundance of Priacanthids along the southwest and northeast coasts of India. The stock parameters of $P$. hamrur estimated from the northwest coast of India (Biradar, 1988; Chakraborty and Vidyasagar, 1996; Varghese, 1995, 1998; Kizhakudan and Zala, 2006) are mostly confined to the waters off Maharashtra. Except for studies by Premalatha (1997) and Sivakami et al. (2001), very little information is available on the fishery, biology and seasonal abundance of $P$. hamrur from the southwest coast of India. The present paper describes the fishery, certain aspects on the biology, population parameters and exploitation level of P. hamrur along Kerala coast. 


\section{Material and methods}

Data on the catch of Priacanthids by commercial trawlers were collected from different landing centres along the Kerala coast from 2007 to 2015. To describe the fishery, monthly and annual estimates of catches made by the Fishery Resource Assessment Division of CMFRI, from the commercial trawlers operated along the Kerala coast were used. A total of 2,500 specimens were measured from the trawl landings at different centres for the study of length frequency and 1,250 specimens were brought to laboratory and cut open to assess the reproductive status. The data on length frequency was grouped into $10 \mathrm{~mm}$ class intervals and raised to get monthly length frequency distribution and later used for age and growth studies.

A total of 641 specimens of $P$. hamrur consisting of 266 males and 375 females, in the size range of 125 to $385 \mathrm{~mm}$ were considered for the study on length weight relationship. The von Bertalanffy growth parameters of $\mathrm{L}_{\infty}$ and $\mathrm{K}$ were estimated using the pooled length frequency data during the period 2014 to 2015, using the ELEFAN 1 module of FiSAT II software (Gayanilo et al., 1996). Total mortality (Z) was estimated using the length-based catch curve method and natural mortality rate (M) by Pauly's empirical equation (Pauly, 1980), taking $27^{\circ} \mathrm{C}$ as the mean seawater temperature. The fishing mortality rate (F) was calculated by subtracting the value of $M$ from $Z$. The probability of capture and size at first capture $\left(\mathrm{L}_{\mathrm{c}}\right)$ were estimated as in Pauly (1984) and the age at zero length (to) from Pauly's (1979) empirical equation, $\log \left(-\mathrm{t}_{0}\right)=-0.392-0.275 \mathrm{log}$ $L_{\infty}-1.038 \log K$. Longevity was calculated as per Pauly (1984), using the equation $t_{\max }=3 / K$. The growth performance index (phi prime index) was calculated from Pauly and Munro (1984) equation, $\phi=\log 10 \mathrm{~K}+2 \log 10 \mathrm{~L}_{\infty}$. Exploitation rate (E) was calculated from $E=F / M+F$ (Sparre and Venema, 1992). The length-structured Virtual Population Analysis (VPA) was carried out for different years using the annual length frequency data. The recruitment pattern was obtained by projecting the length frequency data backwards onto the length axis using the growth parameters obtained (Moreau and Cuende, 1991).

\section{Results and discussion}

\section{Fishery}

During the period 2007-15, Priacanthids contributed on an average $1.32 \%$ of the marine fish landings of Kerala with an average annual landing of 2,577 tonnes (t). The catch initially increased to $5,325 \mathrm{t}$ in 2008, afterwards showed a declining trend up to 2013 , thereafter started increasing and reached maximum of 4,128 $\mathrm{t}$ in 2015 (Fig. 1). The lowest catch of 1,406 $\mathrm{t}$ was recorded in 2013. Though the landings of priacanthids occurred throughout the year, peak landings were observed during August-December. The catch rates of Priacanthids

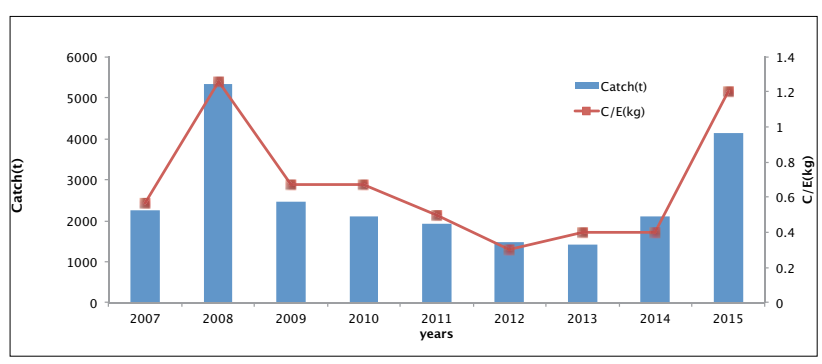

Fig. 1.Catch and catch rate $(\mathrm{CPH})$ of Priacanthids landed by trawlers in Kerala during 2007-15

landed by trawlers were in the range of 0.30 to $1.26 \mathrm{~kg} / \mathrm{h}$ with annual average catch rate of $0.62 \mathrm{~kg} / \mathrm{h}$. The highest catch rate was seen in $2008(1.26 \mathrm{~kg} / \mathrm{h})$, and lowest in $2012(0.29 \mathrm{~kg} / \mathrm{h})$.

The gear-wise landings of Priacanthids in Kerala shows that multiday trawlers contributed to the bulk of the landings (72 $\%)$, followed by multiday trawl nets cum hooks and line (8\%) and outboard units $(21.2 \%)$ which also operated in the same depth range of 30-150 m (Fig. 2).

During the period under study, highest landing was observed in $2008(5,325 \mathrm{t})$ after which the catch showed drastic decline to reach the lowest as $1406 \mathrm{t}$ in 2012. However, the landing showed sudden rise to reach $4,128 \mathrm{t}$ in 2015 . The catch contributed $1.31 \%$ in total trawl landings of Kerala and 71.5 $\%$ among other perches $(32,310$ t). Earlier, Sivakami et al. (2005) reported that off Kerala coast the bull's eye landing showed remarkable increase from 3,965 $t$ in the year 2000 to $11,359 \mathrm{t}$ in 2002, which later declined to $4,445 \mathrm{t}$ in 2004 . The stock of Priacanthids is not uniformly distributed over different latitudes due to its highly moving habits. Premalatha (1997) reported that the catch of Priacanthids seasonally varies which is supported by other authors. Bande et al. (1990) and Sivakami (1990) reported that the peak abundance of this resource on the southwest coast was in August and in the northwest coast was in September. No trend of seasonal abundance was evident in the southeast coast. Vijyakumaran and Naik (1988) reported peak abundance in northeast coast in July and September-November periods. Premalatha (1997)

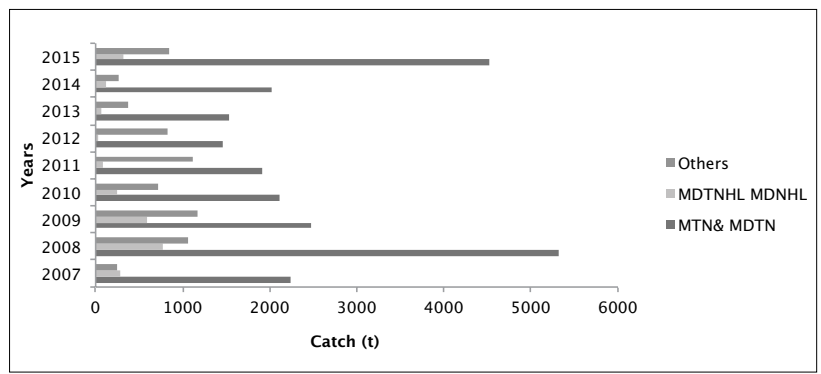

Fig. 2.Gear-wise landings (t) of Priacanthids in Kerala during 2007-15 
reported the peak abundance of these resources in the inshore area is during March-April, July-August and in November at depth range of 40-60 m. John and Sudarsan (1988) reported that $100-200 \mathrm{~m}$ depth zone at $14-16^{\circ} \mathrm{N}$ along the west coast is very productive for bull's eye and stated that the resource inhabits the continental shelf and slope with large concentration in the intermediate zone.

The present study is based on commercial landings from boats operated in depth of 30-150 m along the west coast. The fluctuation in the catches in time and space is indicative of the probable movement of the species between shallow and deeper waters with abundance in the intermediate depth zone up to $150 \mathrm{~m}$ along the west coast. Bande et al. (1990) reported that this resource "migrate" across the shelf and parallel to the shelf, probably depending on "cold water current".

\section{Seasonal abundance}

Priacanthids were landed throughout the year, whereas peak landings were noticed during August (Fig. 3). The average monthly landings during the study period ranged from $729 \mathrm{t}$ in February to 4,714 $\mathrm{t}$ in August. Catch rate in trawl also showed a similar trend showing minimum value in February $(0.27 \mathrm{~kg} / \mathrm{h})$ to maximum of $1.41 \mathrm{~kg} / \mathrm{h}$ in August. Priacanthid landing was more during post-monsoon period of August-October.

In the present study, the maximum abundance of bull's eye along the Kerala coast during 2007-2015 was during MayJune and August-October with peak in August. Sivakami et al. (2005) noticed peak abundance of priacanthids during May-June and August-October. Pillai et al. (1998) based on exploratory surveys stated that Priacanthus spp. (bull's eye) is the most important species available in the coastal waters between Cochin-Mangalore during June-September months as they take advantage of the shoreward movement of the upwelling water and reach comparatively shallower areas of the shelf during the southwest monsoon season as is the case of threadfin breams. However, Biradar (1987) reported that in the northwest coast, high density pockets were noticed during October-December in depth ranges of 50-100 m and lowest during monsoon months.

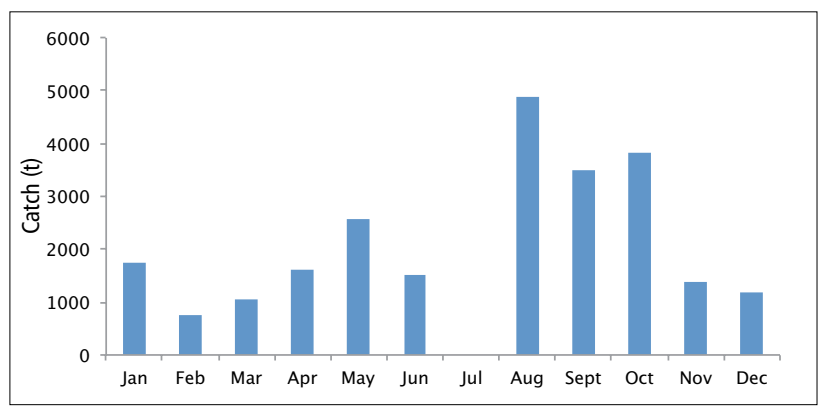

Fig. 3. Average monthly landing of Priacanthids in Kerala during 2007-2015

\section{Species composition}

During the study period, Priacanthus hamrur was the most dominant species in commercial trawl landings all along the Kerala coast contributing over $86 \%$ of Priacanthids and the rest by Heteropriacanthus cruentatus (=Cookeolus boops), (13.8\%). Sivakami et al. (2005) reported that Priacanthids are widely distributed in the Indian seas and the dominant species reported in Indian seas is Priacanthus hamrur. Other species like Heteropriacanthus cruentatus, Cookeolus japonicus, Priacanthus tayenus, P. prolixus, P. sagittarius and Pristigenys niphonia are also seen in catches.

\section{Length composition}

The length range of $P$. hamrur landed in trawl nets was 125-385 $\mathrm{mm}$, with an annual mean length of $235 \mathrm{~mm}$ during the period 2014-15. The length range of $P$. hamrur caught off Veraval coast of Gujarat were 121-339 mm with mean length at 214 $\mathrm{mm}$, at Bombay 61-309 $\mathrm{mm}$ (mean size $=178 \mathrm{~mm}$ ) and Cochin 115-349 mm (mean size $=234 \mathrm{~mm}$ ) (Sivakami et al., 2001)

\section{Length-weight relationship}

The regression equation for length-weight relationship of male and females were calculated as:

Males $: \log w=-4.33415+2.7567 \log L\left(R^{2}=0.94\right)$

Females : $\log w=-4.28149 .+2.7418 \log L\left(R^{2}=0.95\right)$

Males $: W=0.000046328 L^{2.750}$

Females : $\mathrm{W}=0.000052301 \mathrm{~L}^{2.741}$

Analysis of co-variance (ANCOVA) showed that there is no significant difference between slope of male and female $(P>0.001)$, so the data was pooled and a common relationship was obtained for both the sexes combined:

Pooled $: \log w=-4.32762+2.76 \log L\left(R^{2}=0.95\right)$

$W=0.000047038 L^{2.76}$

In Bombay waters, Chakraborty and Vidyasagar (1996) reported the length-weight relationship of $P$. hamrur as $\mathrm{W}=1.59598$ * $L^{2.7715}\left(r^{2}=0.905492\right)$ while at Saurashtra coast, Kizhakudan and Zala (2006) reported the length-weight relationship of $P$. hamrur as $\mathrm{W}=0.00003481 \mathrm{~L}^{2.84}\left(\mathrm{r}^{2}=0.953\right)$. Sivakami et al. (2001) reported the length-weight relationship of $P$. hamrur at Cochin as:

Male $: \log w=-4.034868+2.626081 \log \mathrm{L}(\mathrm{r}=0.981071)$

Female $: \log w=-4.307500+2.743857 \log L(r=0.984473)$

\section{Maturity and spawning}

P. hamrur has an extended spawning season and sheds two 


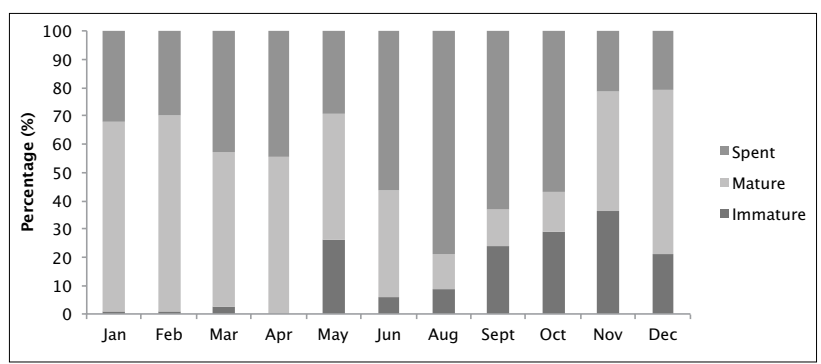

Fig. 4. Percentage occurrence of maturity stages (females) of $P$. hamrur

batches of ova during the extended spawning season (Sivakami et al., 2001). Spent ovaries were represented more during June-October period. Mature ovaries in stage IV to V were observed from November and January-April. The annual sex ratio of $P$. hamrur was 1:1.5. Females were dominant in the fishery. The spawning season of $P$. hamrur was June to October with a peak in August (Fig. 4).

\section{Growth parameters}

The asymptotic length $\left(\mathrm{L}_{\infty}\right)$ and the growth coefficient $(K)$ of the von Bertalanffy growth parameters for $P$. hamrur (VBGF) estimated using ELEFAN 1 (Fig. 5) are $\mathrm{L}_{\infty}=404.25 \mathrm{~mm}, \mathrm{~K}=$ 0.58 year $^{1}$ and $\mathrm{t}_{0}=-0.1370$. The VBGF equation of $P$. hamrur is $L_{t}=404.25\left[1-\mathrm{e}^{-0.58(t+0.1370)}\right]$.

The asymptotic length of $404.25 \mathrm{~mm}$ obtained in the present study is greater than $360 \mathrm{~mm}$ recorded by Chakraborty (1994), Chakraborty and Vidyasagar (1996) and Kizhakudan and Zala (2006) from Bombay waters, whereas is similar to $L_{\infty}$ of 410 $\mathrm{mm}$ estimated by Sivakami et al. (2005) from southwest coast of India. The life span $\left(t_{\max }\right)$ of the fish is estimated as 5 years. The length attained by of $P$. hamrur at the end of I to IV years are 195, 287, $339 \mathrm{~mm}$ and $367.5 \mathrm{~mm}$ respectively. Along the northeast coast of India Philip and Mathew (1996a) reported $\mathrm{L}_{\infty}$ of $283.9 \mathrm{~mm}$ and growth rate 0.37 per year and life span of 8 years. Therefore, it can be inferred that the growth rate of $P$. hamrur off upper east coast is slower than their counter part in the west coast. The reason for this may be attributed to the narrow continental shelf along the east coast with deeper water inhabitation of $P$. hamrurwhich make the species to share some characters of temperate species such as slow growth rate and extended life span (Sivakami et al., 2005).

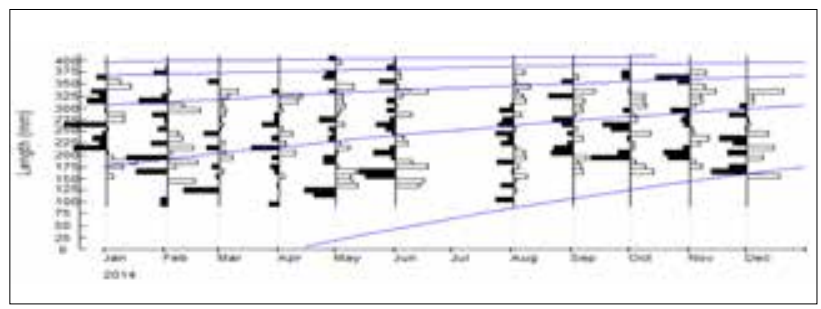

Fig. 5. Restructured growth curve of Priacanthus hamrur off Kerala coast
The growth coefficient of 0.58 per year obtained in the present study is almost equal to the values of $0.64,0.56$, and 0.59 recorded by Chakraborthy and Vidyasagar (1996), Kizhakudan and Zala (2006) and Sivakami et al. (2005) respectively. In the northeast coast, the growth coefficient of $P$. hamrur recorded was 0.38 (Philip and Mathew, 1996a). The growth performance index $(\phi)$ calculated were $4.9,4.8$ and 4.9 by Chakraborty (1994), Chakraborty and Vidyasagar (1996), Kizhakudan and Zala (2006) and Sivakami et al. (2005) respectively which are comparable to the present study (4.97), but varies from the value of 4.47 obtained from northeast coast by Philip and Mathew (1996a).

The longevity $\left(\mathrm{t}_{\max }\right)$ was calculated as 5 years. Accordingly, the total length attained by $P$. hamrur at the end of I to IV years were, $195,287,339 \mathrm{~mm}$ and $367.5 \mathrm{~mm}$ respectively. The size of the largest specimen measured in the fishery was $385 \mathrm{~mm}$.

\section{Mortality and exploitation rates}

Length converted catch curve (Fig. 6) revealed that $50 \%$ of the stock $\left(L_{50}\right)$ became vulnerable to gear when they attained the length of $237.9 \mathrm{~mm}$. $L_{50}$ is found to be higher than the $L_{m}$ of 195 $\mathrm{mm}$ which indicates that the fishes enter the peak exploitation phase after attaining sexual maturity which is desirable for regeneration of the stock.

Virtual Population Analysis (VPA) indicated that maximum fishing mortality occurs at $325 \mathrm{~mm}$ (Fig. 7). The fishing mortality shows an increase from 1.2 to 1.7 with the maximum numbers caught in the size range $275-325 \mathrm{~mm}$. The fishing mortality was low $(<0.1)$ for fishes in the length range of $125-145 \mathrm{~mm}$ and it crossed 1.0 when fishes attained 195

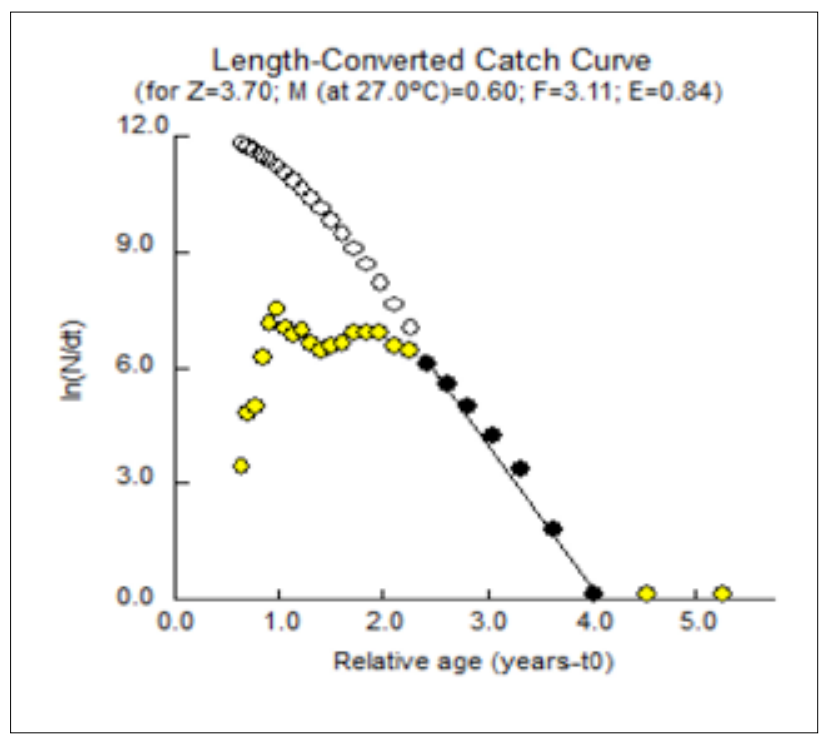

Fig. 6. Length-converted catch curve of $P$. hamrur exploited off Kerala coast 


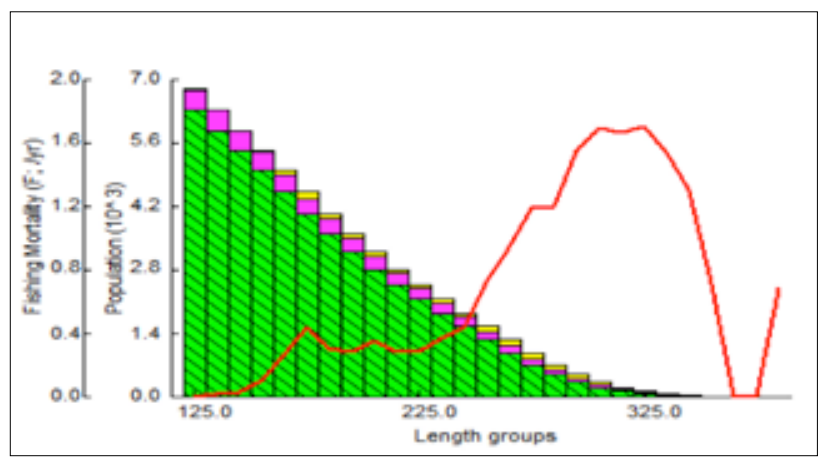

Fig. 7. Virtual Population Analysis (VPA) of $P$. hamrur

$\mathrm{mm}$. Fishing mortality (F) exceeded natural mortality (M) from $245 \mathrm{~mm}$ onwards.

The total morality, Z calculated using the length converted catch curve was 3.70 and natural mortality, M was calculated at 1.13. Fishing mortality (F) obtained was 2.57. Exploitation rate $(\mathrm{E})$ was estimated as 0.69 which is above optimum level of 0.5 . The maximum exploitation rate $\left(\mathrm{E}_{\max }\right)$ of $P$. hamrur in Kerala coast estimated was 0.79 . The $M / K$ ratio obtained in the present study was 1.94 which lies within the normal range of 1-2.5 as suggested by Beverton and Holt (1959). Ingles and Pauly (1984) reported total mortality rate (Z) of 8.09 for Priacanthus tayenus from Samar Sea. Sivakami et al. (2005) reported that the $Z$ ranges between 4.46-6.14 along northwest coast and 3.99-5.45 at southwest coast of India whereas, Philip and Mathew (1996a) reported total mortality from northeast coast as 2.50 . The natural mortality rate estimated in the present study was 1.13 and the fishing mortality $(F)$ is estimated at 2.59. The fishing mortality rate estimated by Sivakami et al. (2005) ranged from 3.32 to 5 along the northwest coast and 1.13-4.31 in the southwest coast of India.

There is a great difference in the estimates of natural mortality of $P$. hamrurfrom different locations by different authors. John and Sudarshan (1988) estimated $M$ value in the range of 1.7-1.9 for $P$. hamruralong the entire Indian coast. Biradar (1988) reported M for $P$. hamrur off Bombay waters as 1.0, while Chakraborty (1994) estimated M as 1.52 along the Maharashtra coast. From the northeast coast, Philip and Mathew (1996a) reported M of 0.93 for $P$. hamrur. Chakraborty (1994) stated that the natural mortality should be related to size, since larger fish as a rule would have lesser predators. The $M / K$ ratio obtained for the fish was 1.94 which lies within the normal range of 1-2.5 suggested by Beverton and Holt (1959).

Studies on the recruitment pattern show peak recruitment during October and minor one during March-April (Fig. 8). This is in close agreement with the results of maturation and spawning which indicate peak season of spawning of $P$. hamrur during August. A minor peak is seen during March-April as a result of November-January spawning.

The exploitation rate (E) estimated for $P$. hamrur in the present

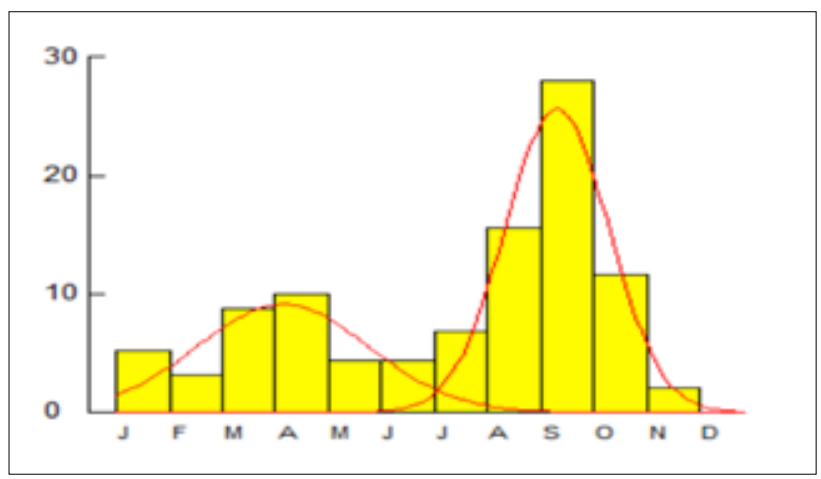

Fig. 8. Recruitment pattern of $P$. hamrur off Kerala coast

study was 0.69 which indicates that the resource off Kerala coast is exploited at levels above the optimum value of 0.5 suggested by Gulland (1975). The E value recorded by Chakraborty (1994) from Bombay waters was 0.50 and 0.51 by Kizhakudan and Zala (2006) from Veraval coasts. Sivakami et al. (2005) reported $E$ value of 0.73 from southwest coast while from the northeast coast of India Philip and Mathew (1996 a) estimated the exploitation rate as 0.63 .

The landing of priacanthids along Kerala coast show upward trend after 2013. Maximum landing takes place in August as trawlers immediately after the monsoon ban ventures into the sea when fish is available in plenty in the mid shelf region brought in by the upwelled waters along with other demersal resources like threadfin breams. Exploratory surveys indicated that Priacanthids are potential deep water resource located all along the southwest and east coasts in 50-400 m depth zone. The exploitation of the species is on the rise since it has got a good demand in local market in fresh as well as in processed form. Exploitation of the resource by deep sea trawlers all along the southwest coast is rising and the situation has come to such a stage that the resource now shows signs of exploitation above optimum levels as evidenced from the present study. Therefore, care has to be taken to avoid overexploitation of the stock.

\section{Acknowledgements}

The authors are grateful to the Director, CMFRI, Kochi for facilities and encouragement and the staff of Demersal Fisheries Division, CMFRI, Kochi for help and support.

\section{References}

Bande, V. N., N. Gopinathan and K. Balachandran. 1990. Studies on the distribution and abundance of Bull's eye (Priacanthus spp.) in the EEZ of India. Proc. First Workshop Scient. Result. FORV Sagar Sampada, 5-7 June 1989, Cochin, p. 233-235. 


\section{P. K. Seetha et al.}

Beverton, R. J. H. and S. J. Holt. 1959. A review of the lifespans and mortality rates of fish in nature and their relation to growth and other physiological characteristics. In: G. E. W. Wolstenholme and M. O'Connor (Eds.), CIBA Foundation colloquia on ageing, 5: 142-180.

Biradar, R. S. 1987. Stock assessment of demersal offshore fishery resources off the Karnataka coast. Fish. Technol., 24 (2): 83-87.

Biradar, R. S. 1988. Estimates of stock density, biomass and maximum sustainable yield of Priacanthus hamrur (Forsskal) off the northwest coast of India. Fish. Surv. India Spl. Pub., 2: 55- 65.

Chakraborty, S. K. 1994. Fishery, age, growth, mortality and stock assessment of Priacanthus hamrur (Forskal) from Bombay Waters. Bull. Cent. Mar. Fish. Res. Inst., 47: 121-127.

Chakraborty, S. K. and K. D. Vidyasagar. 1996. Growth, mortality and stock assessment of two perches, moon tail bull's eye Priacanthus hamrur (Perciformes/ Priacanthidae) and thorny cheekgrouper (Epinephelus diacanthus) (Perciformes/ Serranidae) from Bombay waters. Indian J. Mar. Sci., 25 (4): 312-315.

Gayanilo, F. C. Jr., P. Sparre and D. Pauly. 1996. The FAO-ICLARM Stock Assessment Tools (FiSAT) User's Guide. FAO Comp. Info. Ser. (Fish), No. 8, FAO, Rome, $126 \mathrm{pp}$.

Gulland, J. A. 1975. Manual of methods for fisheries resource survey and appraisal, Part 5. Objectives and basic methods. FAO Fish. Tech. Pap., 145: 29 pp.

Ingles, J. and D. Pauly. 1984. An atlas of the growth, mortality and recruitment of Philippine fishes. /CLARM Tech. Pap., 13: 127 pp.

John, M. E. and D. Sudarsan. 1988. Assessment of the stock of big eye snappers (Fam. Priacanthidae) in Indian seas with a note on their pattern of abundance. Symp. Tropical Marine Living Res., 12-16 January, 1988, Cochin. Abst. No. 232.

Kizhakudan, Shoba Joe and M. S. Zala. 2006. Dynamics of Priacanthus hamrur (Forsskal) exploited off Saurashtra coast. Indian J. Fish., 53(4): 409-416.

Moreau, J. and F. X. Cuende. 1991. On improving the resolution of the recruitment pattern of fishes. ICLARM Fishbyte, 9: 45-46.

Pauly, D. 1979. Theory and management of tropical multi-species stocks. A review with emphasis on the south-east Asian demersal fisheries. ICLARM Stud. Rev., 1: 35 pp.

Pauly, D. 1980. On the interrelationships between natural mortality, growth parameters and mean environmental temperature in 175 fish stocks. ICES J. Mar. Sci., 39 (2): $175-192$.

Pauly, D. 1984. Fish population dynamics in tropical waters: a manual for use with programmable calculators. ICLARM Stud. Rev., 8: 325 pp.

Pauly, D. and J. L. Munro. 1984. Once more on the comparison of growth in fish and invertebrates. ICLARM Fishbyte, 2 (1):21.
Philip, K. P. and K. Mathew. 1996a. Growth, mortality and exploitation of Priacanthus hamrur (Forsskal) from the northeast coast of India. J. Mar. Biol. Ass. India, 38(1\&2): 106-113.

Philip, K. P. and K. Mathew. 1996b. Length-weight relationship and relative condition factor in Priacanthus hamrur. Fish. Technol., 33 (2): 79-83.

Pillai, V. N., V. V. Singh, P. Krishnakumar and A. Nandakumar. 1998. Presence of upwelled water in the shelf region along the northeast coast of India towards the end of the southwest monsoon season and its possible effect on the migration of bull's eye (Priacanthus spp.) into shallower areas of the continental shelf. In: M. Mohan Joseph, N. R. Menon and N. Unnikrishnan Nair (Eds.), The Fourth Indian Fisheries Forum Proceedings, 24-28 November 1996, Cochin. Asian Fisheries Society Indian Branch, Mangalore, 519 pp.

Premalatha, P. 1997. On the fishery and biology of Priacanthus hamrur Forsskal along the southwest coast of India. Indian J. Fish., 44 (3): 265-270.

Sivakami, S. 1990. Observations on the demersal fishery resources of the coastal and deep sea areas of the EEZ of India. Proc. First Workshop Scient. Resul. FORV Sagar Sampada, 5-7 June, 1989, Cochin, p. 215-233.

Sivakami, S., E. Vivekanandan, P. Nammalwar, M. Feroz Khan, P. U. Zacharia, G. Mohanraj, Grace Mathew and P. Jayasankar. 1998. The non-conventional finfish resources of the Indian EEZ. In: M. S. Hameed and B. M. Kurup (Eds.), Tech. Adv. Fish., Publ. No. 1, School of Industrial Fisheries, Cochin University of Science and Technology, Cochin, p. 243-255.

Sivakami, S., S. G. Raje, M. Feroz Khan, J. K. Shoba, E. Vivekanandan and U. Rajkumar 2001. Fishery and biology of Priacanthus hamrur (Forsskal) along the Indian coast. Indian J. Fish., 48 (3): 277-289.

Sivakami, S., S. G. Raje, K. V. S. Nair, P. P. Manoj Kumar and K. Ramani. 2005. Fishery potential of bull's eyes along the west coast of India J. Mar Biol. Ass. India, 47 (2): 185-192.

Sparre, P. and S. C. Venema. 1992. Introduction to tropical fish stock assessment, Part I, Manual. FAO Fish. Tech. Pap., 306: 376 pp.

Varghese, S. 1995. Biological aspects and stock assessment of the deep sea fish Priacanthushamrur (Forsskal) of the northwest coast of India. M. Sc. Thesis, Mumbai University.

Varghese, S. 1998. Length weight relationship of Priacanthus hamrur along the northwestern Indian EEZ. Bull. Fish. Surv. India, 26: 51-54.

Vijayakumaran, K. and S. K. Naik. 1988. Study of the stock of Priacanthus hamrur (Forsskal) during March and September between lat. $11-16^{\circ} \mathrm{N}$ along the west coast of India. Fish. Surv. India. Spl.Publ., 2: 106-119. 